\title{
DESIGN OF WLAN AND WIMAX BAND REJECTION UTILIZING UWB PLANAR ANTENNA COMPRISING SLIT IN THE CONDUCTOR PLANES
}

\author{
Siti Fatimah Jainal ${ }^{1}$, Norliza MOHAMEd ${ }^{2}$ AND AZURa HAMZah ${ }^{3}$ \\ ${ }^{I}$ Faculty of Engineering, Lincoln University College (LUC), Kelana Jaya, Selangor, Malaysia. \\ ${ }^{1,3}$ Malaysia Japan International Institute of Technology, UTM Kuala Lumpur, Malaysia. \\ ${ }^{2}$ Razak Faculty of Technology and Informatics, UTM Kuala Lumpur, Malaysia. \\ *Corresponding author: sitifatimah@lincoln.edu.my
}

(Received: $2^{\text {th }}$ February 2019; Accepted: $30^{\text {th }}$ July 2019; Published on-line: $2^{\text {nd }}$ December 2019)

\begin{abstract}
A compact and low profile ultra wideband planar antenna comprises dual notched-band characteristics for WIMAX and WLAN are presented. UWB communication system is allocated between 3.1 and $10.6 \mathrm{GHz}$, which coexisted with the WLAN and WIMAX frequency bandwidths at 3.3 to $3.6 \mathrm{GHz}$, and 5 to $6 \mathrm{GHz}$, repsectively. The coexistence between multiple frequency bandwidths possibly can cause interference into the communication systems such as data loss and signal disruption. Thus, it is essential to eliminate the coexisted frequency bandwidhs from UWB spectrum. The UWB planar antenna is costructed with a radiator of an elliptical-shaped, and half-ground element which is subjected to suppress the frequency bandwidth for 3.3 to 3.7 and 5 to $6 \mathrm{GHz}$. Slits are engraved in the elliptical radiator and ground element by etching the conductor elements. Slit shapes are designed in simple and optimized to realize the maximum band notch characteristics. Slit placements are scrutinized and the band notch characteristics are determined. It is considered that the slit in the ground element and the elliptical radiator have stimulated the band notches frequency bandwidths for 3.3 to 3.7 and 5 to $6 \mathrm{GHz}$, respectively. The UWB planar antennas are compared with the reference antenna and the results are verified. Measured reflection coefficient $S_{11}$ for band notch peaks at the WLAN and WIMAX frequency bandwidths are about -3.0 and $-4.0 \mathrm{~dB}$, respectively. Radiation pattern co-polarizations in the $\mathrm{H}$ - and E-plane are in omni- and bi-directional, respectively. Maximum gain $G$ is located in the $-z$-axis and $-x$-axis in $\mathrm{H}$ - and E-plane in the frequency of interest. Surface currents are distributed in the slit areas. Slits in the elliptical radiator and the ground element are not substantially affect the UWB planar antenna overall performances.
\end{abstract}

ABSTRAK: Antena jalur lebar paling satah yang padat dan bersusuk rendah telah diperkenalkan dan terdiri daripada dua ciri lebar-takik bagi WIMAX dan WLAN. Sistem komunikasi UWB berada pada 3.1 dan $10.6 \mathrm{GHz}$, bertindan dengan jalur lebar frekuensi WLAN dan WIMAX yang berada pada 3.3 hingga $3.6 \mathrm{GHz}$, dan 5 hingga $6 \mathrm{GHz}$, masingmasing. Sifat bertindan antara beberapa jalur lebar frekuensi mungkin akan menyebabkan gangguan pada sistem komunikasi seperti kehilangan data dan gangguan isyarat. Oleh itu, adalah penting bagi membuang jalur lebar frekuensi yang bertindan dengan spektrum UWB. Antena satah UWB telah dibina dengan radiator pemancar berbentuk elips, dan unsur separuh-bumi (lapisan asas) dibawah jalur lebar frekuensi pada 3.3 hingga 3.7 dan 5 hingga $6 \mathrm{GHz}$. Jalur celahan telah diukir pada radiator elips dan lapisan asas dengan mengukir unsur konduktor. Jalur celahan telah direka mudah dan dioptimumkan bagi mencapai jalur takik maksimum. Kedudukan jalur celahan diteliti dan ciri-diri jalur takik diperolehi. Jalur celahan pada lapisan asas dan radiator elips diperhatikan menyebabkan frekuensi jalur lebar takik sebanyak 3.3 hingga 3.7 dan 5 hingga $6 \mathrm{GHz}$, masing-masing. 
https://doi.org/10.31436/iiumej.v20i2.1097

Antena satah UWB dibandingkan dengan antena rujukan dan dapatan kajian telah disahkan tidak mempengaruhi keputusan antena planar UWB dengan ketara. Ukuran pantulan pekali $S_{11}$ yand diukur pada frekuensi jalur lebar takik WLAN and WIMAX adalah -3.0 dan $-4.0 \mathrm{~dB}$, masing-masing. Corak pancaran radiasi ko-polar pada satah $\mathrm{H}-$ dan E- adalah omni- dan bi-arah, masing-masing. Kekuatan isyarat maksima $G$ berada di paksi $-z$ dan $-x$ pada satah $H$ - dan E- pada frekuensi yang dipilih. Elektrik pada permukaan tersebar dalam kawasan jalur celahan. Celah radiator elips dan lapisan asas tidak mempengaruhi prestasi keseluruhan antena satah UWB.

KEY WORDS: ultra wideband, planar antenna, WLAN, WIMAX, and slit

\section{INTRODUCTION}

Ultra wideband (UWB) frequency bandwidth is assigned from 3.1 to $10.6 \mathrm{GHz}$ and has been commonly applied for communications and sensors, position location and tracking [1], wireless monitoring of transplanted organs [2], monitoring human's activities such as sport and quality of sleep by using wireless body network (WBAN) [3], sensor to detects positioning and tracking of a target by a quad-copter and target [4], detection of human's body behind wall [5], and indoor positioning, radar/medical imaging and target sensor data collection [6-7]. Ultra wideband communication system benefits such as high data rate transfer, less path loss and better immunity to multipath propagation, availability in lowcost transceivers, and low transmit power and low interference, and the requirements in the means of reducing interference due to the coexistence with other narrowband systems have been discussed in [6]. UWB antenna has been proposed in [8] in the means of improving its performances by using conductive adhesive of carbon composite. UWB frequency bandwidth coexisted with other narrowband system and the UWB communication characteristics has been compared with single co-channel interference for various materials of partitions in real environments such as brick board, cloth office partition, concrete block, dry-wall, plywood, structure wood, and single co-channel, had been investigated in [9] where the study shows that the channel capacity had degraded with interference for mostly on the drywall partition and found lowest for structural wood partition.

UWB interference has been studied in [10] and channel loss estimation using the Okumura channel and tested within the ZigBee circuit with dual-power. Possible interference between an indoor UWB system and an outdoor fixed wireless access (FWA) system operating in the 3.5-5.0 GHz has been discussed in [11]. Multiband-orthogonal frequency-division multiplexing (MB-OFDM) coexistence with time hopping ultrawideband (TH-UWB) networks has been studied analytically in the means of modeling the interference for TH-UWB [12]. Mutual interference performance has been studied in [13] by performing pulse shaping from UWB to other narrowband system. The wavelet technique and reduction of interference from other narrowband system to UWB system in conjunction with Transmitted-Reference (TR-UWB) signaling scheme with adaptive receiver is utilized. Multiple access interference in the bi-orthogonal modulation for UWB communication systems performances has been investigated in [14]. UWB interference such as UWB activity or UWB density is a critical matter when protecting WiBro performance and analytical method based on a system level simulation of a WiBro (OFDMA) is proposed in [15]. The narrowband interferences which had affected the wideband system has been investigated and characterized in [16-17]. Interference from a UWB transmitter into a narrowband receiver has been studied in [18]. 
https://doi.org/10.31436/iiumej.v20i2.1097

The impacts of ultra wideband in narrowband interferences have also been investigated in [19-22] and had described the degradation of the system, and although filtering can be used in the system in the means of correcting the narrowband interference, it has failed in at high interference level. The analysis of the effect of narrowband interference on UWB system in the presence of multipath fading had demonstrated narrowband problems at certain condition as stated in [23]. UWB signals had encountered many interference sources primarily from narrowband systems and also had affected many narrowband radios as described in [24].

Thus, studies have been indicating that the coexistence between multiple frequency bandwidths could cause interferences to other communication systems. The effects could be in signal degradation, data loss, buzzing sound and communication error. Furthermore, more severe effects could have been resulted by the interference such as system failure and malfunction. Thus, it is essential to eliminate the coexistence frequency bandwidth from the UWB frequency bandwidth.

There are various methods to suppress the mutual narrowband interference (NBI) in UWB communication system. Chirp waveforms of two non-linear UWB based on the arctrigonometric and archperbolic variable is proposed in the means of alleviating the narrowband interference (NBI) in [25]. The effect of interference to bit error rate performance which used the time hopping pulse modulation for impulse radio ultrawideband is analyzed in [26]. Method of using chirp waveforms of non-linear in the means of suppressing the interference of narrowband in UWB communication system has been explained in [27]. Band-stop filter is applied to prevent the narrowband interference (NBI) in a receiver for transmitted-reference ultra-wideband (TR-UWB) systems consists of narrowband interference (NBI) and inter-pulse interference (IPI) mitigation [28]. A null phase-shift polarization (NPSP) which combined a linear polarization-vector transformer (PVT), single notch polarization (SNP) filter and an amplitude and phase compensator (APC) has been proposed in [29] to suppress narrowband interference (NBI). Elimination of narrowband interference (NBI) could use antenna design modification as an option. The method is simple and low profile as it requires the etching of the conductor element of the antenna which has been reported [30-38]. Structure for the reference and proposed antenna were discussed in section 2. Results were substantiated in section 3 and then concluded in section 4 , respectively.

\section{STRUCTURES OF UWB PLANAR ANTENNAS}

Slit placements in the elliptical radiator and ground element are simulated in the early stage for UWB planar antenna type 2A and 2B. Slit is etched in four points known as point $\mathrm{a}, \mathrm{b}, \mathrm{c}$, and d, consecutively as depicted in Figure 1. Slit is etched in one-sided of the elliptical element and ground plane as it is in symmetric. Thus, the results would be in identical. The elliptical radiator and ground element is divided into two parts (lower and upper). The origin is placed in the middle point of the elliptical radiator and ground element, respectively. Slit is positioned in the centre of the lower and upper area of the elliptical radiator and ground plane. The point coordinates for the slit placement a, b, c, and d are tabulated in Table 1. Slit placements are simulated consecutively and the reflection coefficients $S_{11}$ are compared. Band notch characteristics are studied in the means of achieving the desired band notch frequency bandwidths. Slit placements are optimized in order to obtain the optimum band notch characteristics for UWB planar antenna type 2A, and $2 \mathrm{~B}$, respectively. The finalized slit configurations are listed in Table 2. 


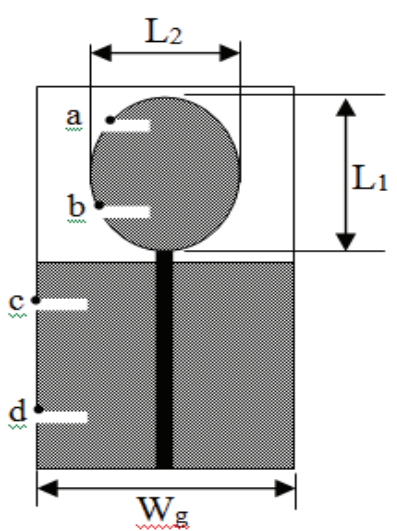

a) Top view

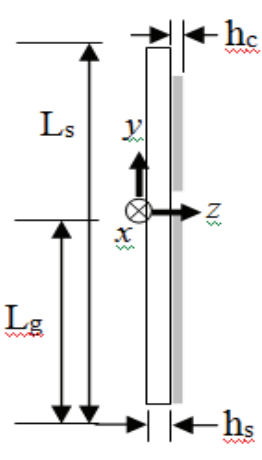

b) Side view

Fig. 1. Slit placements for UWB planar antenna

Table 1: Slit placements in the elliptical element and ground plane

\begin{tabular}{cc}
\hline Point & $\mathbf{P}(\mathbf{x}, \mathbf{y}, \mathbf{z})$ \\
\hline a & $\mathrm{P}(-6,12,0.035)$ \\
b & $\mathrm{P}(-6,4,0.035)$ \\
c & $\mathrm{P}(-11,-6,0.035)$ \\
d & $\mathrm{P}(-11,18,0.035)$ \\
\hline
\end{tabular}

Table 2: Parameters for slit $\mathrm{S}_{1}$ and $\mathrm{S}_{2}$

\begin{tabular}{ccll}
\hline Antenna type & Slit type & Parameter & Dimension \\
\hline \multirow{3}{*}{ 2A } & Length, $l$ & $7.12 \mathrm{~mm}$ \\
& $\mathrm{~S}_{1}$ & Width, $w$ & $1.10 \mathrm{~mm}$ \\
& & Slope angle, $\theta$ & $7.98 \mathrm{deg}$ \\
& & Length, $l$ & $11.0 \mathrm{~mm}$ \\
& $\mathrm{~S}_{2}$ & Width, $w$ & $0.60 \mathrm{~mm}$ \\
& & Slope angle, $\theta$ & $39.43 \mathrm{deg}$ \\
\hline \multirow{3}{*}{ 2B } & & Length, $l$ & $8.28 \mathrm{~mm}$ \\
& $\mathrm{~S}_{1}$ & Width, $w$ & $0.13 \mathrm{~mm}$ \\
& & Slope angle, $\theta$ & $1.38 \mathrm{deg}$ \\
& & Length, $l$ & $11.27 \mathrm{~mm}$ \\
& $\mathrm{~S}_{2}$ & Width, $w$ & $0.60 \mathrm{~mm}$ \\
& & Slope angle, $\theta$ & $41.04 \mathrm{deg}$ \\
\hline
\end{tabular}

The reference, UWB planar antenna type 2A, and 2B structures are illustrated in Figure 2 and the dimensions are tabulated in Table 3. UWB planar antenna type $2 \mathrm{~A}$ and $2 \mathrm{~B}$ substrates used FR-4 with the permittivity $\varepsilon_{r}$ of 4.6 and 4.4, respectively. The dielectric electric tangent delta $\delta$ is given 0.019 . Size of the reference antenna is compact. The conductor planes are placed one-sided on the substrate and half-ground element is used. Thickness of the substrates for UWB planar antenna type 2A and 2B are different due to the value of the substrate permittivity $\varepsilon_{r}$, thus to achieve impedance matching. 
UWB planar antenna type 2A and 2B used the thickness $h_{s(2 A)}=1.6$ and $h_{s(2 B)}=0.76 \mathrm{~mm}$, respectively. However, the conductor planes thickness and the size of the antenna are maintained. Impedance matching is achieved by determining the eccentricity $e$ of the elliptical radiator as Eq. 1.

$$
e=\sqrt{\frac{L_{2}^{2}}{L_{1}^{2}}}
$$

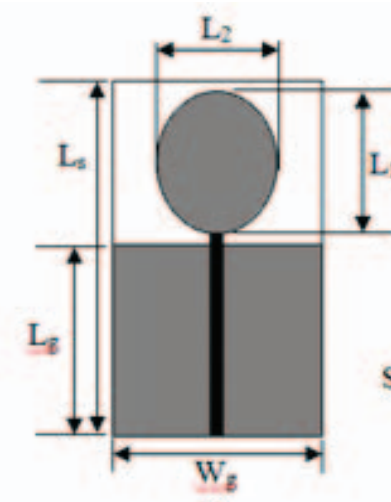

(a)

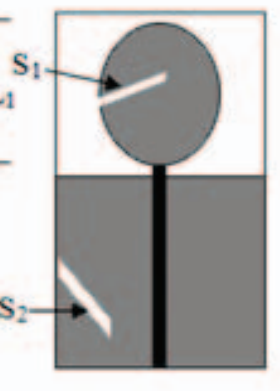

(b)

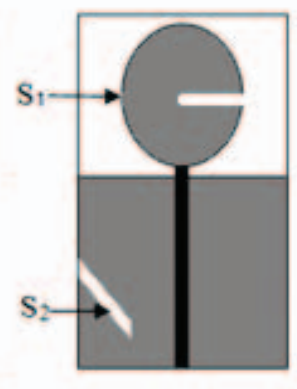

(c)

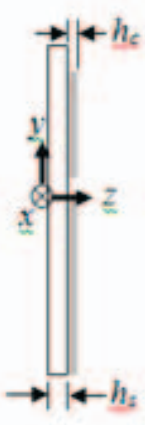

(d)

Fig. 2. UWB planar antenna (a) reference (b) type $2 \mathrm{~A}$ (c) type $2 \mathrm{~B}$ (d) side view

Table 3: Parameters for UWB planar antenna

\begin{tabular}{cc}
\hline Parameter & Dimension [mm] \\
\hline $\boldsymbol{L}_{\boldsymbol{s}}$ & 45 \\
$\boldsymbol{L}_{\boldsymbol{g}}$ & 24 \\
$\boldsymbol{L}_{\boldsymbol{1}}$ & 16 \\
$\boldsymbol{L}_{\boldsymbol{2}}$ & 12.8 \\
$\boldsymbol{w}_{\boldsymbol{g}}$ & 21 \\
$\boldsymbol{h}_{\boldsymbol{c}}$ & 0.035 \\
$\boldsymbol{h}_{\boldsymbol{s}(2 \boldsymbol{A})}$ & 1.6 \\
$\boldsymbol{h}_{\boldsymbol{s}(2 \boldsymbol{B})}$ & 0.76 \\
$\boldsymbol{\varepsilon}_{\boldsymbol{r}(2 \boldsymbol{A})}$ & 4.6 \\
$\boldsymbol{\varepsilon}_{\boldsymbol{r}(2 \boldsymbol{B})}$ & 4.4 \\
\hline
\end{tabular}

Slits are engraved in the elliptical radiator and the ground element, respectively. Slit is etched in the middle side of the elliptical radiator for UWB planar antenna type 2A and 2B. However, slit in the UWB planar antenna type $2 \mathrm{~A}$ is etched slanted compare with slit in horizontal for type $2 \mathrm{~B}$. Slit configurations are determined by the impedance matching and to optimize the reflection coefficient $S_{11}$. Higher value of the reflection coefficient $S_{11}$ is desired for the band notch characteristics. Slit in the ground plane is etched slanted and downwards in about at the centre of the ground plane. Slit configurations in the ground plane are quite similar to each other for UWB planar antenna type 2A and $2 \mathrm{~B}$.

However, slits in the elliptical element have major different in slit width $w$ and slope angle, $\theta$. Theoretically, this is owing to the difference in the substrate permittivity $\varepsilon_{r}$, and slit $S_{1}$ and $S_{2}$ configurations are counted in the means of optimizing the band notch characteristics. Generally, surface current distributions are drifted in the elliptical element compared in the ground plane owing to the feed point. Therefore, slit placements in the elliptical element have become critically affected the band notch characteristics compared in the ground plane, where the surface current is disseminated inferiorly. 
https://doi.org/10.31436/iiumej.v20i2.1097

Simulation procedure was depicted in Figure 3. First step is to set the simulation setting. Simulation parameters such as boundary, background, and frequency bandwidth are encoded. Optimization is carried out in the means of achieving the optimum band notch characteristics for UWB planar antenna type 2A and 2B. Reference and UWB planar antenna type 2A and $2 \mathrm{~B}$ are simulated by time domain in Computer Simulation Software (CST) using Antenna-Planar (Microwave/Radio Frequency/Optical) module. Simulation frequency is allocated between 3 and $11 \mathrm{GHz}$. The boundary condition and reflection level are given in open-space and 0.0001 , respectively.

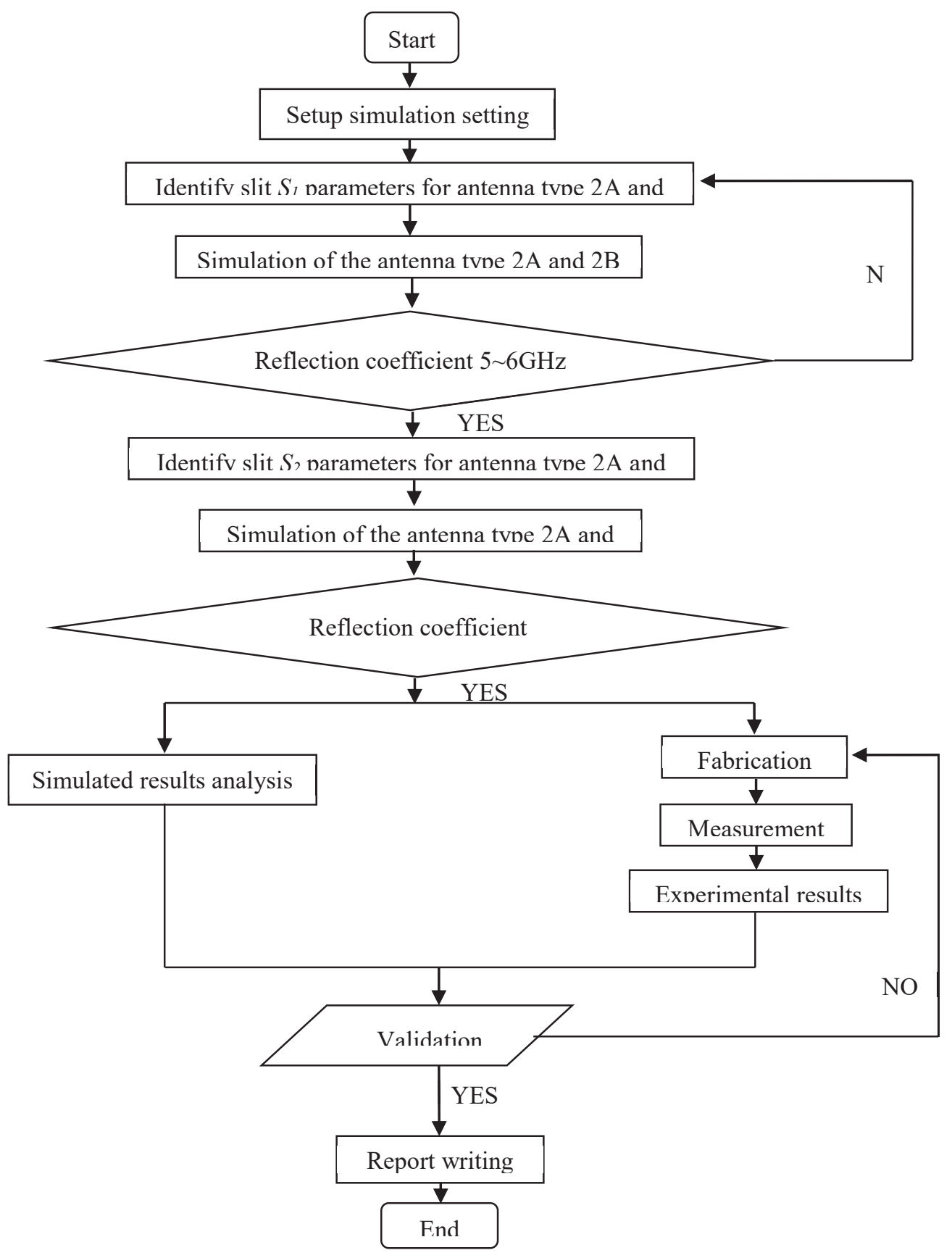

Fig. 3. Workflow for UWB planar antenna

The open boundary is in convolution perfect match layer (CPML) for minimizing the reflection at the boundary during simulation. UWB planar antenna operating frequency is 
https://doi.org/10.31436/iiumej.v20i2.1097

between 3.1 and $10.6 \mathrm{GHz}$, thus the reflection coefficient $S_{11}$ must be below -10dB between this frequency bandwidth. However, the reflection coefficients $S_{11}$ for the band notch frequency bandwidths must be above $-10 \mathrm{~dB}$ level in the means of eliminating the band notch frequency bandwidths. The higher reflection coefficients $S_{11}$ level between the band notch frequencies bandwidths the better eliminations of the band notch frequency bandwidths.

\section{RESULT AND DISCUSSION}

The reference, UWB planar antenna type 2A, and 2B performances are compared after optimization of the band notch characteristics by adjusting the slits parameters. It is desired that the UWB planar antenna type 2A and 2B performances are unchanged when compared with the reference antenna. Thus, it is substantiated that the slits existence on the conductor elements not significantly changes the UWB planar antenna type $2 \mathrm{~A}$ and $2 \mathrm{~B}$ performances. The UWB planar antennas are compared with [39-40] as their structures are nearly similar to the UWB planar antenna and etching method also been used for the band notching, and the results are comparable. However, the slits structures are more complicated compared to the UWB planar antennas. The reflection coefficients $S_{11}$ for the band notch peaks are in the same range. The radiation patterns also exhibit in omni-directional and bi-directional for the $\mathrm{H}-$ and E-plane, respectively similar to the UWB planar antennas. The numbers of lobes are increased for higher frequency regions. The maximum gains $G$ for the UWB planar antenna is comparable with [39-40] as the maximum gain is achieved at $6.9 \mathrm{~dB}$. However, the overall gains $G$ for [40] is lower than the UWB planar antennas. It is considered that the slit structures in the radiator could affect the overall gain $G$ of the designed antenna due to slit in [40] is considered larger than the UWB planar antenna. Reflection coefficient $S_{11}$, surface current distribution, radiation patterns, gain, and efficiency are discussed in sub-section 3.1, 3.2 , and 3.3, consecutively.

\subsection{Reflection coefficient}

Reflection coefficient $S_{11}$ for eccentricity $e$ and slits placement is depicted in Figure 4 and 5, consecutively. Band notch characteristics for the slit placements are tabulated in Table 4 . The reflection coefficient, $S_{11}$ level for operating frequency, $f$ is known below -10 $\mathrm{dB}$. The frequency bandwidths for $4.3 \sim 4.9$ and $7.3 \sim 8.7 \mathrm{GHz}$ are located above $-10 \mathrm{~dB}$ when $e=0$, where as for $3.3 \sim 8.3$ and $8.8 \sim 11 \mathrm{GHz}$ when $e=1$, for type A. Frequency bandwidths were to be found at $8.7 \sim 9.3 \mathrm{GHz}$ for $e=0$, and are placed for 3.6 9 and 9.7 11 GHz for $e=1$, for type $\mathrm{B}$ respectively. The results substantiate that eccentricity $e=0.6$ is ideal for type $2 \mathrm{~A}$ and $2 \mathrm{~B}$ as it is within the operating frequency level. Centre frequencies $f_{c}$ for slit placements at point $\mathrm{A}$ for type $2 \mathrm{~A}$ and $2 \mathrm{~B}$ is located at 6.7 and $7.3 \mathrm{GHz}$, respectively. Point $\mathrm{D}$ is located at 4.4 and $4.3 \mathrm{GHz}$ for type $2 \mathrm{~B}$, respectively. Thus, point $\mathrm{A}$ and $\mathrm{D}$ are adjusted in the means of realizing band notch characteristics for $5 \sim 6$ and 3.3 3.7GHz, respectively. Reference and UWB planar antenna type $2 \mathrm{~A}$ and $2 \mathrm{~B}$ were simulated and measured. The comparisons for the reflection coefficient $S_{11}$ are presented in Fig. 6, respectively. 


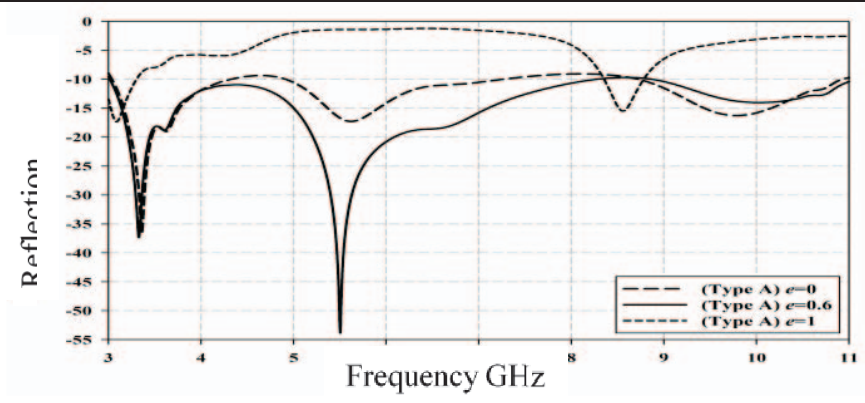

(a) Type $2 \mathrm{~A}$

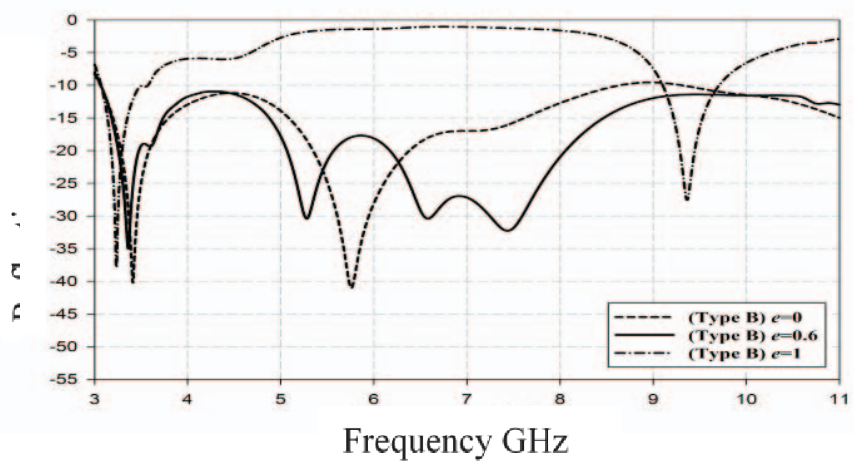

(b) Type 2B

Fig. 4. Reflection coefficient, $S_{11}$ due to eccentricity $e$

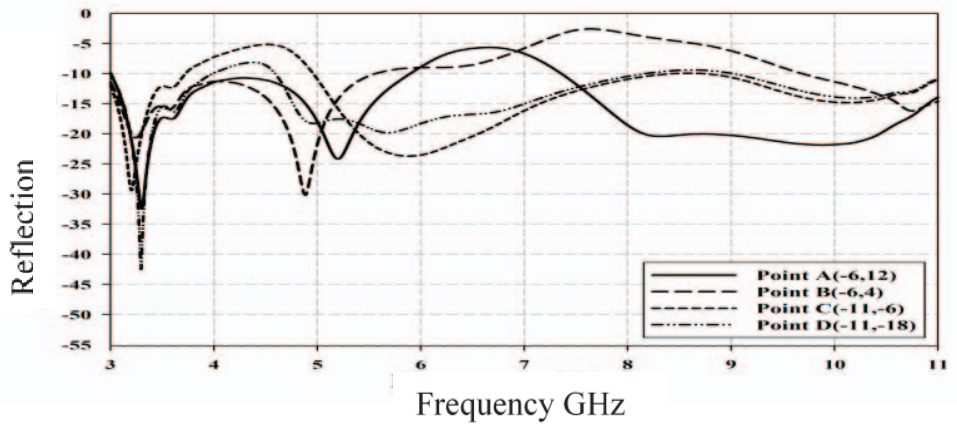

(a) Type A

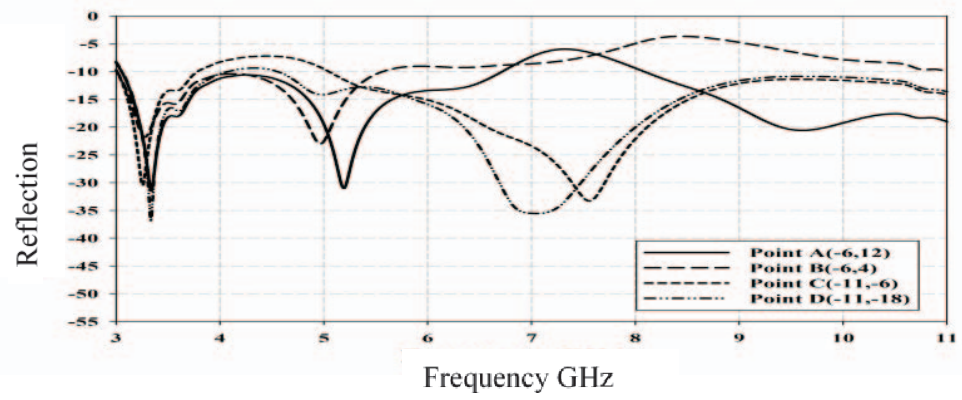

(b) Type B

Fig. 5. Reflection coefficient $S_{11}$ for slit placements 
https://doi.org/10.31436/iiumej.v20i2.1097

Table 4: Band notch characteristics due to slit placements

\begin{tabular}{cccc}
\hline $\begin{array}{c}\text { Antenna } \\
\text { type }\end{array}$ & Point & $\begin{array}{c}\text { Centre frequency, } \\
\boldsymbol{f}_{\boldsymbol{c}}[\mathbf{G H z}]\end{array}$ & $\begin{array}{c}\text { Reflection coefficient, } \\
\boldsymbol{S}_{\boldsymbol{1}}[\mathbf{d B}]\end{array}$ \\
\hline & $\mathrm{a}$ & 6.7 & -5.7 \\
$\mathrm{~A}$ & $\mathrm{~b}$ & 7.6 & -2.5 \\
& $\mathrm{c}$ & 4.5 & -5.1 \\
& $\mathrm{~d}$ & 4.4 & -8.1 \\
\hline & $\mathrm{a}$ & 7.3 & -6.0 \\
B & $\mathrm{b}$ & 8.4 & -3.6 \\
& $\mathrm{c}$ & 4.4 & -6.9 \\
& $\mathrm{~d}$ & 4.3 & -9.2 \\
\hline
\end{tabular}

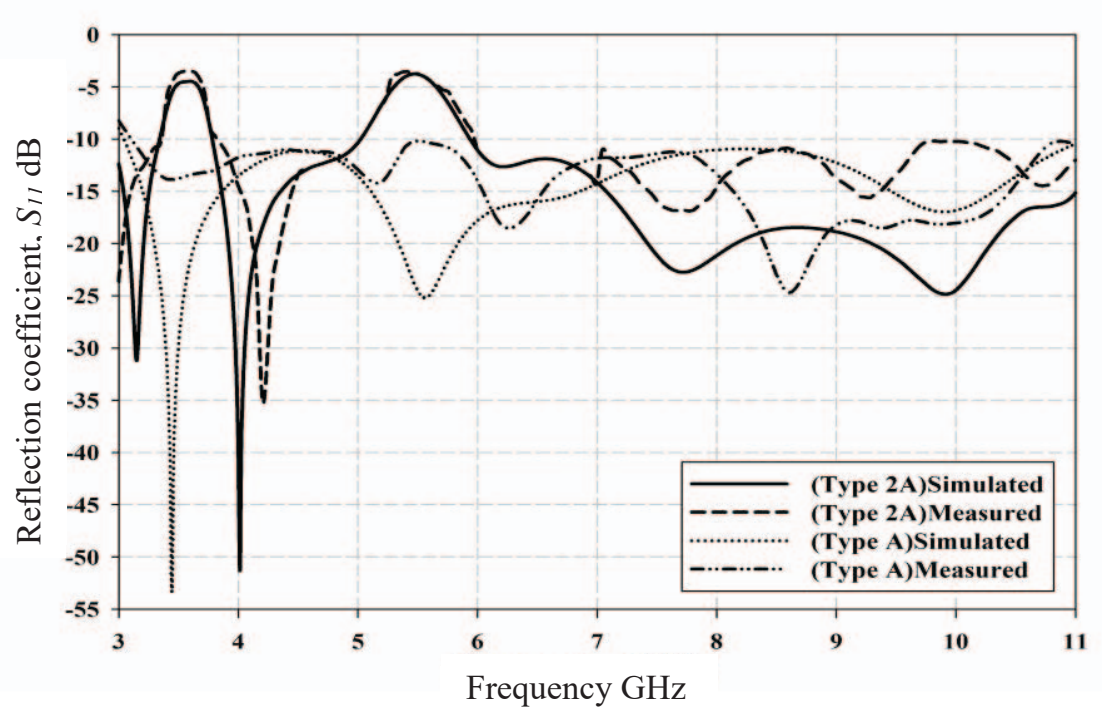

(a) Type $2 \mathrm{~A}$

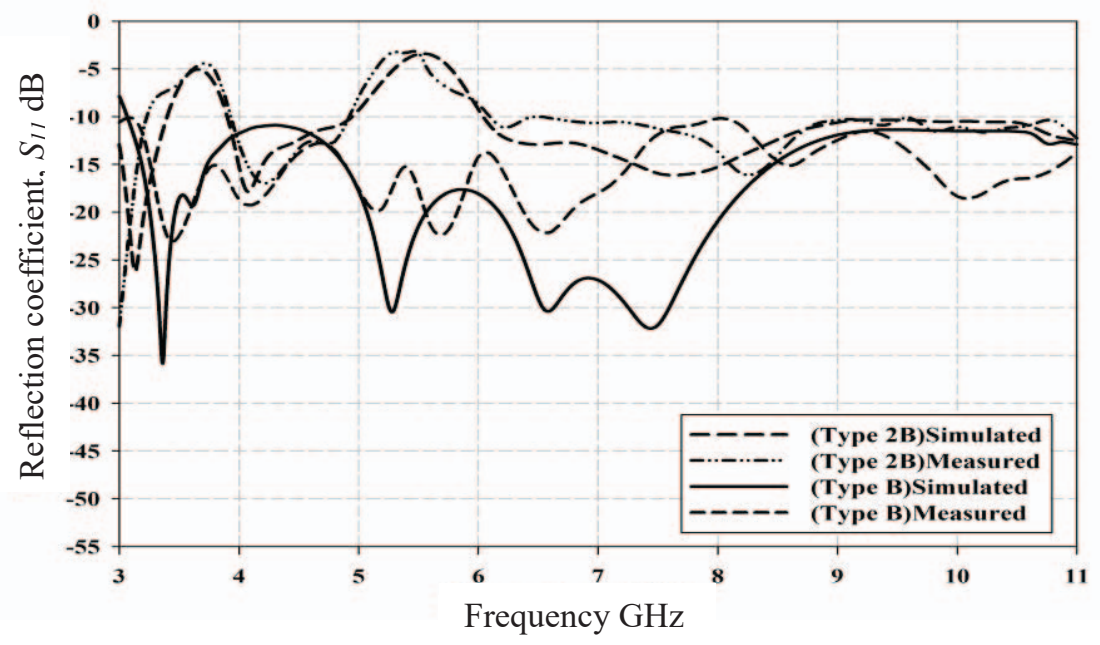

(b) Type 2B

Fig. 6. Finalized reflection coefficient, $S_{11}$ for reference and UWB planar antenna type $2 \mathrm{~A}$ and $2 \mathrm{~B}$

$\mathrm{BN} 1$ and BN2 are known as the band notch characteristics realized for the frequency bandwidth at 5 6 and 3.3 3.7GHz, correspondingly. The dual notched-band characteristics 
https://doi.org/10.31436/iiumej.v20i2.1097

for UWB planar antenna type 2A and $2 \mathrm{~B}$ are tabulated in Table 5. It is substantiated that dual band notch are generated due to the slits in the elliptical radiator and ground element. The slit in the elliptical radiator and ground element are considered to generate the notchedband at the frequency bandwidth in $5 \sim 6 \mathrm{GHz}$ and $3.3 \sim 3.7 \mathrm{GHz}$, correspondingly. Theoretically, it is considered that the frequency bandwidths for $5 \sim 6$ and $3.3 \sim 3.7 \mathrm{GHz}$ are suppressed from the UWB communication system. Simulated and measured results are compared and results have shown reasonable agreement between both.

Table 5: Dual band notch characteristics performances for UWB planar antenna type $2 \mathrm{~A}$ and $2 \mathrm{~B}$

\begin{tabular}{|c|c|c|c|c|c|}
\hline & \multirow{2}{*}{\multicolumn{2}{|c|}{ Antenna type }} & \multicolumn{3}{|c|}{ Band notch characteristic } \\
\hline & & & $\begin{array}{c}\text { Centre } \\
\text { frequency, } f_{c} \\
{[\mathrm{GHz}]}\end{array}$ & $\begin{array}{c}\text { Reflection } \\
\text { coefficient, } S_{11} \\
{[\mathrm{~dB}]}\end{array}$ & $\begin{array}{c}\text { Frequency } \\
\text { bandwidth, } \\
f_{b w}[\mathrm{GHz}]\end{array}$ \\
\hline \multirow{4}{*}{$2 \mathrm{~A}$} & \multirow{2}{*}{ Simulated } & BN1 & 5.5 & -3.7 & 1.0 \\
\hline & & $\mathrm{BN} 2$ & 3.6 & -4.4 & 0.4 \\
\hline & \multirow{2}{*}{ Measured } & BN1 & 5.4 & -3.4 & 1.0 \\
\hline & & $\mathrm{BN} 2$ & 3.6 & -3.3 & 0.4 \\
\hline \multirow{4}{*}{ 2B } & \multirow{2}{*}{ Simulated } & BN1 & 5.6 & -3.3 & 1.0 \\
\hline & & $\mathrm{BN} 2$ & 3.6 & -5.0 & 0.4 \\
\hline & \multirow{2}{*}{ Measured } & BN1 & 5.4 & -3.2 & 1.0 \\
\hline & & $\mathrm{BN} 2$ & 3.7 & -3.4 & 0.5 \\
\hline
\end{tabular}

\subsection{Surface current distributions}

Surface current distributions for the reference and UWB planar antenna type 2A, and 2B for the centre frequency $f_{c}, 3.5$ and $5.5 \mathrm{GHz}$ are exemplified in Table 6 . Surface currents are centralized around the slits area. Theoretically, the surface currents surge vertically in the elliptical radiator and ground element. Slits are sited horizontally to intercept the vertically-polarized surface current and consequently mismatched the input impedance in the antenna. Surface currents are surged in the edges of the ground element in the lower frequency area and mainly in the elliptical radiator in the middle frequency region. Surface current is surged in slit in the ground plane and elliptical element for the frequency 3.5 and $5.5 \mathrm{GHz}$, respectively. Hence, it is contemplated that slit in the ground plane and elliptical element have generated the band notch characteristics in the UWB planar antenna type $2 \mathrm{~A}$ and $2 \mathrm{~B}$, accordingly.

\subsection{Radiation patterns}

Radiation patterns $R P$, gain $G$ and efficiency $e_{f f}$ of the reference, UWB planar antenna type $2 \mathrm{~A}$, and $2 \mathrm{~B}$ are exhibited in Fig. 7 and 8 , consecutively. It is demonstrated that the radiation patterns in the $\mathrm{H}$ - and E-plane for the UWB planar antenna type 2A and 2B is in omni- and bi-directional, respectively. Radiation patterns in the H-plane of the UWB planar antenna type $2 \mathrm{~A}$ and $2 \mathrm{~B}$ is comparable with the monopole antenna. This is as a result of the vertically positioned of the feeding cable on the ground plane. Radiation patterns $R P$ performances are tabulated in Table 7. It is corroborated that the higher gain $G$ is pointed in the $-z$-axis and $-x$-axis in H- and E-plane, correspondingly. However, maximum gain $G$ for the frequencies of interest 7.5 and $9.5 \mathrm{GHz}$ for UWB planar antenna type $2 \mathrm{~B}$ in the $\mathrm{E}-$ plane is pointed in the $+x$-axis. 
Table 6: Surface current distributions for reference antenna and UWB planar antenna type $2 \mathrm{~A}$ and $2 \mathrm{~B}$

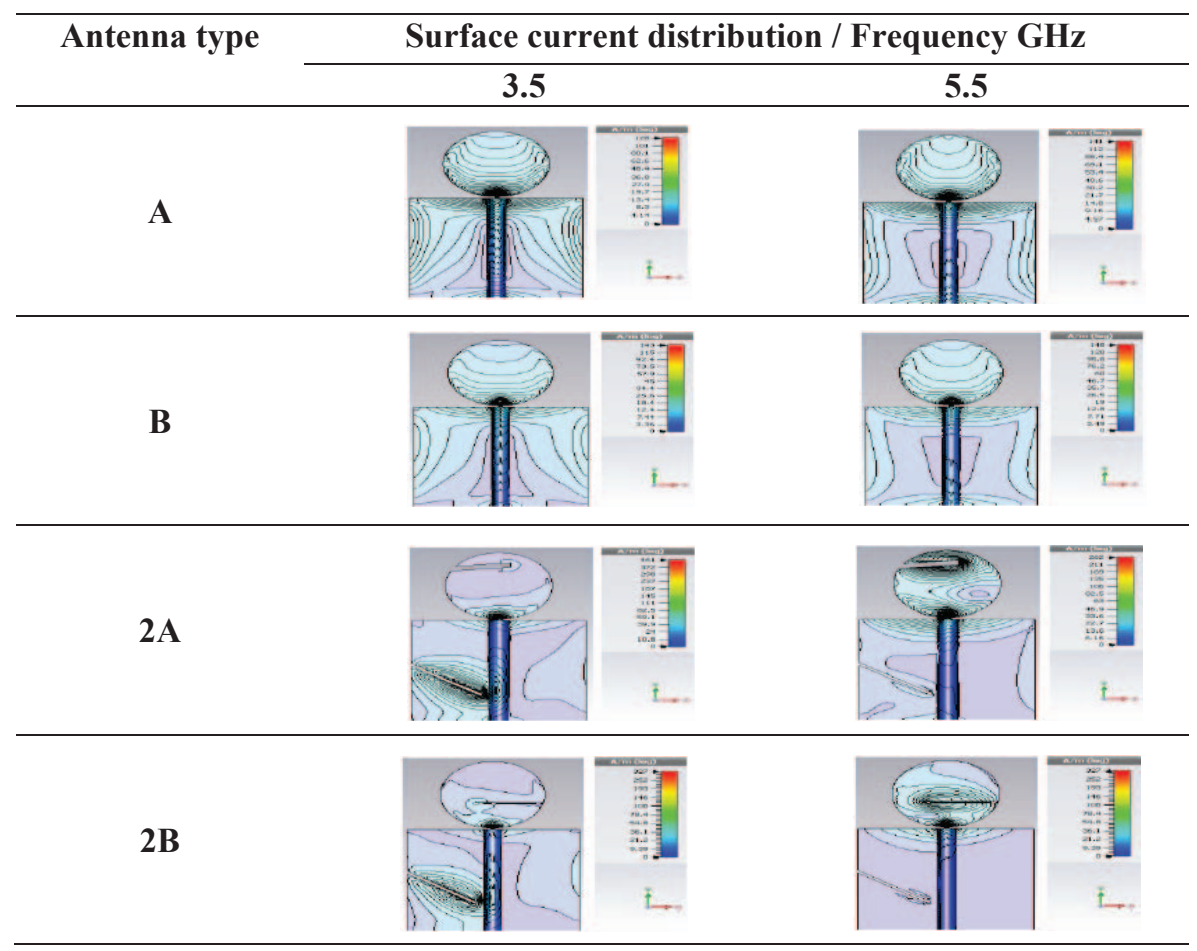

It is considered that the slit in the elliptical radiator is placed in the $+x-$ axis, hence has influenced the radiation patterns of the UWB planar antenna type $2 \mathrm{~B}$, accordingly. Radiation patterns of the reference are equated with UWB planar antenna type $2 \mathrm{~A}$ and $2 \mathrm{~B}$, and the results are passable. It is preferred that the performances for UWB planar antenna type $2 \mathrm{~A}$ and $2 \mathrm{~B}$ not significantly amended from the reference antenna. Radiation efficiency $e_{f f}$ for the frequency $5 \sim 6$ and $3.3 \sim 3.7 \mathrm{GHz}$ have substantiated deterioration for the UWB planar antenna type $2 \mathrm{~A}$ and $2 \mathrm{~B}$, correspondingly. It is demonstrated that the band notch are realized in the respective frequency bandwidths, accordingly.

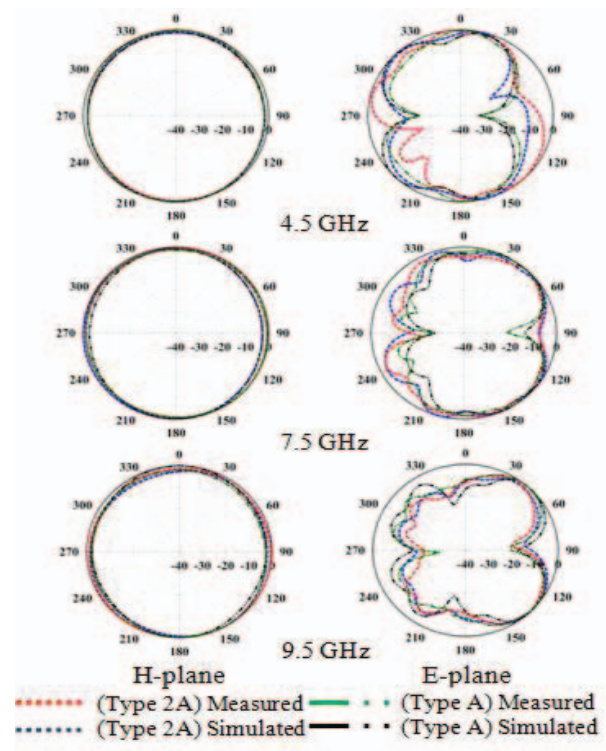

(a) Type $2 \mathrm{~A}$

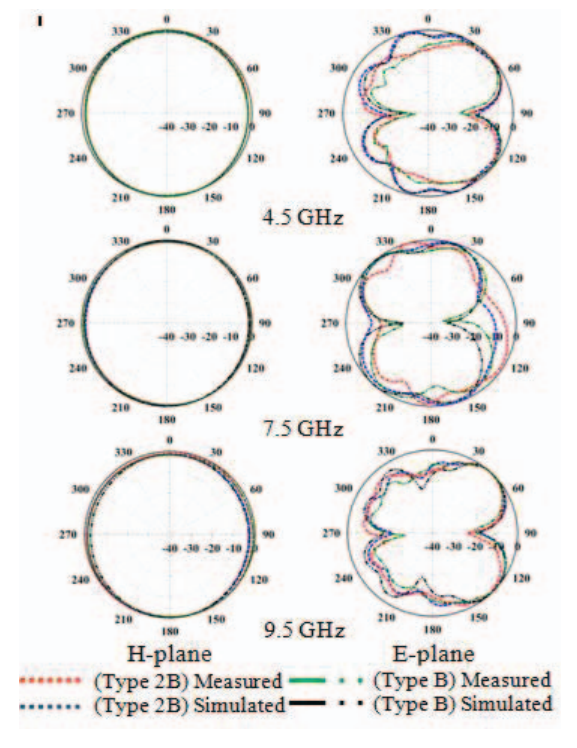

(b) Type 2B

Fig. 7. Radiation patterns for UWB planar antenna type $2 \mathrm{~A}$ and $2 \mathrm{~B}$ 


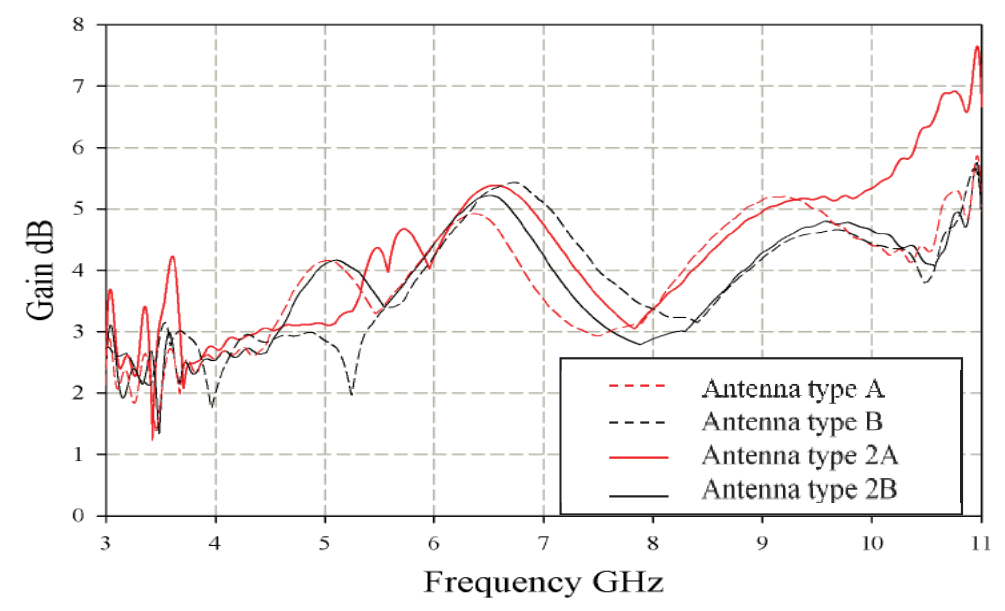

(a) Gain $G$

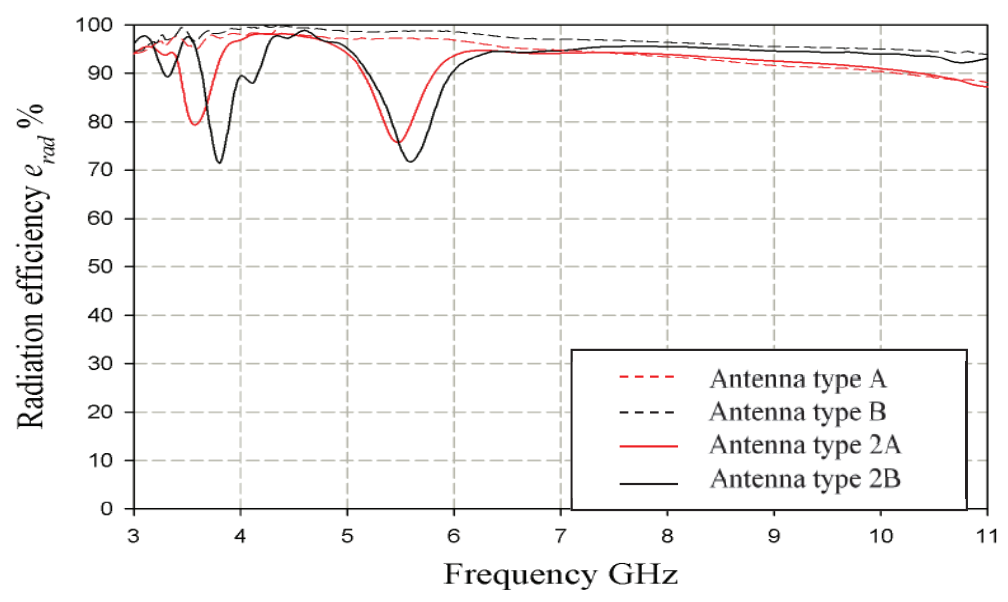

(b) Efficiency $e_{f f}$

Fig. 8. Gain $G$ and efficiency $e_{f f}$ for UWB planar antenna type $2 \mathrm{~A}$ and 2B

Table 7: Radiation pattern performances for UWB planar antenna type 2A and 2B

\begin{tabular}{cccccccc}
\hline \multirow{2}{*}{$\begin{array}{c}\text { Antenna } \\
\text { type }\end{array}$} & $\begin{array}{c}\text { Frequency } \\
\text { GHz }\end{array}$ & \multicolumn{2}{c}{ Main lobe plane } & \multicolumn{2}{c}{ Efficiency \% } & \multicolumn{2}{c}{ Gain dB } \\
\cline { 3 - 8 } & & H- & E- & Simulate & Measured & Simulated & Measured \\
\hline \multirow{2}{*}{ 2A } & 4.5 & 180 & 162 & 96.2 & 94.2 & 3.6 & 6.3 \\
& 7.5 & 258 & 196 & 94.0 & 100.0 & 3.6 & 4.8 \\
& 9.5 & 173 & 136 & 91.7 & 83.9 & 5.3 & 4.8 \\
\hline \multirow{2}{*}{ 2B } & 4.5 & 177 & 164 & 94.8 & 81.3 & 2.9 & 5.4 \\
& 7.5 & 172 & 347 & 95.5 & 100.0 & 4.0 & 5.4 \\
& 9.5 & 181 & 42 & 94.4 & 87.5 & 4.7 & 4.9 \\
\hline
\end{tabular}




\section{CONCLUSION}

UWB planar antenna comprises dual notched-band characteristics to decline the frequency bandwidth for WIMAX and WLAN are presented. The method employed in the design is simple and low profile. Slits in the elliptical radiator and ground element apparently have initiated the band notch characteristics in UWB planar antenna type 2A and 2B. The structure of the reference and UWB planar antenna type 2A and 2B uses halfground plane, and designs are compact. The impedance mismatched is corresponded with the surface currents distributions in the slits area, respectively. The reflection coefficients $S_{11}$ have decreased promptly at the notched-band frequency bandwidths and have achieved about -3.0 and $-4.0 \mathrm{~dB}$ at the center frequency 5.5 and $3.5 \mathrm{GHz}$, respectively. Gain $G$ values are plunged at the band notch center frequencies, 5.5 and $3.5 \mathrm{GHz}$ to 4.0 and $3.5 \mathrm{~dB}$, respectively. Radiation efficiency $e_{r a d}$ for the UWB planar antennas have dropped to $70 \%$ from the overall performances. Thus, it is indicated that the frequency bandwidths for 5 to 6 and 3.3 to $3.7 \mathrm{GHz}$ are suppressed from the UWB frequency bandwidth, accordingly. However, the radiation patterns for the UWB planar antennas are compared with the reference antenna and have indicated that it is not significantly affected by the slits in the conductor elements. The UWB planar antenna type $2 \mathrm{~A}$ and $2 \mathrm{~B}$ performances are evaluated with the reference antenna and the results are verified.

\section{ACKNOWLEDGEMENT}

This research work is funded by Universiti Teknologi Malaysia (UTM) through Razak grant fund vote No. 4J283. Antenna measurements were conducted in Antenna Research Center (ARG), Faculty of Engineering (FOE), Universiti Teknologi Mara (UITM-Shah Alam).

\section{REFERENCES}

[1] Applications on uwb technology. Available: https://arxiv.org/abs/0911.1681.

[2] Pongphan Leelatien, Koichi Ito, Kazuyuki Saito, Manmohan Sharma, Akram Alomainy. (2018) Channel characteristics and wireless telemetry performance of transplanted organ monitoring system using ultra wideband communication. IEEE Journal of Electromagnetics, RF and Microwaves in Medicine and Biology, 2(2):94-101.

[3] Timo Kumpuniemi, Juha Pekka Makela, Matti Hamalaine, Kamya Yekeh Yazdandoost, Jari Iinatti. (2017) Dynamic uwb off-body radio channels-human body shadowing effect. Available: 10.1109/PIMRC.2017.8292584.

[4] Robust target-relative localization with ultra-wideband ranging and communication. Available: https://researchgate.net/publication/324602380.

[5] Jawad Ali, Roshayati Yahya, Noorsaliza Abdullah, Syarfa Zahirah Sapuan. (2017) Ultrawideband antenna for behind the wall detection. International Journal of Electrical and Computer Engineering (IJECE), 7(6):2936-2941.

[6] Ultra wideband antennas-past and present. Available: https://www.researchgate.net/ publication/46093503.

[7] Weihua Zhuang, Xuemin Sheman Shen Qi Bi. (2003) Ultra-wideband wireless communications. Wireless Communications and Mobile Computing, 3:663-685.

[8] Erick Reyes-Vera, Mauricio Arias-Correa, Andreas Giraldo-Munoz, Daniel Catano-Ochoa, Juan Santa-Marin. (2017) Development of an improved response ultra-wideband antenna based on conductive adhesive of carbon composite. Progress in Electromagnetics Research C, 79:199-208.

[9] Chien-Ching Chiu, Chun-Liang Liu, Shu-Han Liao. (2011) Channel characteristics of ultrawideband systems with single co-channel interference. Wireless Communications and Mobile Computing, 13:864-873. 
https://doi.org/10.31436/iiumej.v20i2.1097

[10] Lei Gao, Qun Chen. (2017) Channel loss estimation and test of ultra-wideband propagation from 2 to $10 \mathrm{ghz}$ application. Indonesian Journal of Electrical Engineering and Computer Science, 6(3):663-670.

[11] Romeo Giuliano, Gianluca Guidoni, Ibrahim Habib, Franco Mazzenga. (2004) Evaluation of interference due to uwb hot spot on fixed wireless access systems. J. Wireless Communications and Mobile Computing, 4:947-961.

[12] Farshad Sarabchi, Chahe Nerguizian. (2015) Impact of th-uwb interference on mb-ofdm uwb systems: interference modeling and performance analysis. Wireless Communications and Mobile Computing, 16:960-976.

[13] Bikramaditya Das, Ch. Sasmita Das, Susmita Das. (2010) Interference cancellation schemes in uwb systems used in wireless personal area network based on wavelet based pulse spectral shaping and transmitted reference uwb using awgn channel model. International Journal of Computer Applications, 2(2):88-93.

[14] Simone Morosi, Romano Fantacci, Enrico Del Re, Leornardo Goratti. (2005) Performance of the bi-orthogonal modulation for ultra-wideband communication systems with multiple access interference. Wireless Communications and Mobile Computing, 5:5-14.

[15] Young-Keun Yoon, Heon-Jin Hong, Ik Guen Choi. (2007) Ultra-wideband coexistence with wibro. J. ETRI, 29(2):234-236.

[16] J.R. Foerster. (2002) The performance of a direct-sequence ultra wideband system in the presence of multipath, narrowband interference, and multiuser interference. IEEE Conference on Ultra Wideband Systems and Technologies, 21-23 May. Baltimore (USA), 87-91.

[17] N.G. Ferrara, M.Z.H. Bhuiyan, and S. Soderholm. (2018) A new implementation of narrowband interference detection, characterization, and mitigation technique for a softwaredefined multi-gnss receiver. Avaible:https//researchgate.net/326784680.

[18] K.Siwiak. (2001) Impact of ultra wide band transmissions on a generic receiver. IEEE VTS $53^{\text {rd }}$ Vehicular Technology Conference, 6-9 May. Rhodes (Greece), 1181-1183.

[19] A.Taha, and K.M.Chugg. (2002) A theoretical study on the effects of interference uwb multiple access impulse radio. Available:https://ieeexplore.org/abstract/document/1197276.

[20] J.Bellorado, S.S.Ghassemzadeh, L.J.Greenstein, T.Sveinsson, and V.Tarokh. (2003) Coexistence of ultra-wideband systems with iee-802.11a wireless lans. Available:https://ieeexplore.ieee.org/abstract/document/1258271.

[21] Kai Shi, Yi Zhou, Burak Kellici, Timothy Wayne Fischer, Erchin Serpedin, and Aydin Iker Karsilayan. (2007) Impacts of narrowband interference on ofdm-uwb receivers:analysis and mitigation. IEEE Transactions on Signal Processing, 55(3):1118-1128.

[22] A.Giorgetti, M.Chiani, and M.Z.Win. (2005) The effect of narrowband interference on wideband wireless communication systems. IEEE Transactions on Communications, 53(12):2139-2149.

[23] Xiaoli Chu, and R.D.Murch. (2004) The effect of nbi on uwb time-hopping systems. IEEE Transactions on Wireless Communications, 3(5):1431-1436.

[24] Ananthram Swami, B.M.Sadler and J.Turner. (2001) On the coexistence of ultra wideband and narrowband radio systems. Available:https//researchgate.net/publication/3937675.

[25] Zhiquan Bai, Xiatong Li, Dongfeng Yuan, Kyungsup Kwak. (2010) Non-linear chirp based on uwb waveform design for suppression of nbi. Wireless Communications and Mobile Computing, 12:545-552.

[26] Yamen Issa, Iyad Dayoud, Waala Hamouda. (2015) Performance analysis of multiple-input multiple-output relay networks based impulse radio ultra-wideband. Wireless Communications and Mobile Computing, 15:1225-1233.

[27] Hanbin Shen, Weihua Zhang, Kyung Sup Kwak. (2007) Non-linear chirp uwb ranging system with narrowband interference suppression abilities. J. ETRI, 29(4):521-523.

[28] S.Cui, K.C.Teh, K.H.Li, Y.L.Guan, C.L.Law. (2009) Performance analysis of transmittedreference UWB systems with narrowband interference suppression. Wireless Communications and Mobile Computing, 9:1081-1088. 
https://doi.org/10.31436/iiumej.v20i2.1097

[29] Xing Peng Mao, Jon W.Mark. (2008) Polarization filtering for narrowband interference suppression in ultra-wideband communications. Wireless Communications and Mobile Computing, 8:941-952.

[30] A compact fractal uwb antenna with open-ended quarter wavelength slot for band notch characteristics.Available:https://www.researchgate.net/publication/229566986.

[31] A WLAN notched wideband monopole antenna for ultra-wideband communication applications. Available: https://www.researchgate.net/publication/324463199.

[32] Circular slotted monopole printed antenna with grounded stub WLAN band-notch for UWB applications. Available: https://doi.org/10.1080/1448837X.2018.1452331.

[33] Dual-band shared-aperture UHF/UWB RFID reader antenna of circular polarization. Available: https://www.researchgate.net/publication/325327219.

[34] Dual notch band UWB antenna with improved notch characteristics. Available: https://www.researchgate.net/publication/323646136.

[35] Hemachandra R.Gorla, Frances J.Harackiewicz. (2015) Dual trident uwb planar antenna with band notch for wlan. Progress in Electromagnetics Research Letters, 54:115-121.

[36] Novel design of dual band-notched rectangular monopole antenna with bandwidth enhancement for UWB applications. Available: https://www.researchgate.net/ publication/325380975.

[37] Muhibbur Rahman, Jung-Dong Park. (2018) The smallest form factor uwb antenna with quintuple rejection bands for iot applications utilizing rsrr and rcsrr. National Center for Biotechnology Information US National Library of Medicine (NCBI) 18(911):1-16.

[38] Ammar Alhegazi, Zahriladha Zakaria, Noor Azwan Shairi, Sharif Ahmed, Tole Sutikno. (2017) UWB filtenna with electronically reconfigurable band notch using defected misrotrip structure. Indonesian Journal of Electrical Engineering and Computer Science, 8(2):302-307.

[39] Soufian Lakrit, Sudipta Das, Ali El Alami, Debaprasad Barad, Sraddhanjali Mohapatra. (2019) A compact uwb monopole patch antenna with reconfgurable band nocthed characteristics for Wi-MAX and WLAN applications. AEU International Journal of Electronics and Communications. Available: https://www.science direct.com/science/article/pii/S1434841119303048.

[40] Bing Gong, Chuang Ma, Fan Jing, Yaling Hou, Ruibing Shen. (2018) A novel uwb antenna with two ultra narrow and closely space notched bands. Journal of Physics, 1176(2019), 1-7. 